\title{
Application of plug-in real time Hot-Spot detection system into PV peak bridge method in PV generation system 太陽光発電システムにおける Plug-in リアルタイムホットスポット検出システムの PV ピークブ リッジ法への適用
}

\author{
Naoaki IIZUKA, Kazutaka ITAKO, Masataka OCHIAI and Bakhsh HOSSAM \\ Kanagawa Institute of Technology, 1030 Shimoogino, Atsugisi, Kanagawa, 243-0292 Japan \\ TEL: +81-46-291-3152 FAX: +81-46-291-3152 e-mail: itako@ele.kanagawa-it.ac.jp \\ (Received 27 January, $2017 \quad$ Accepted 15 February, 2017)
}

Currently, the production and installation quantity of photovoltaic modules has been increasing rapidly. Meanwhile, the failure cases are also increasing. Accordingly, many failures are results of the Hot-Spot phenomenon. This is a phenomenon in which the entire or part of the defective cell becomes hot when shadow occurs on the cell for a long period. In severe cases, the phenomenon causes breaking of the cell and a fire. While there are many Hot-Spot inspection methods, such as using infrared cameras, the inspection instruments of these methods are expensive, and these methods also require a lot of time and effort during the inspection. Previously, the authors proposed a Hot-Spot detection system included into PCS. In this paper, we proposed plug-in type Hot-Spot detection system, and report about effectiveness of the system.

Keywords : PV Generation System, Hot-Spot, PV Modules

\section{INTRODUCTION}

近年、日本では固定価格買取制度の実施により、太陽 電池モジュールの生産数及び導入数が増加している。そ れに伴い、設置から年数が経過したモジュールの故障件 数も増加している。故障原因の一つに、ホットスポット 現象がある。図 1 にホットスポットの発生してるモジュ 一ルの例を示す。ホットスポット現象とは、久陥セルに 長時間影が生じると、セル温度が非常に高くなる現象で ある。このホットスポット現象によって、セルの破壊や 火災などを引き起こす危険性がある。従来のホットスポ ット検査法として、サーモグラフィによる温度検査があ るが、検査時間や労力を要するなどの問題点がある。ま た、ホットスポットは検査時に発生していなくても、常 に発生する可能性があるため、リアルタイムでホットス ポットを監視することが求められている。

先に、筆者らは主に新設の太陽光発電システムを対象

SAS Award was given to this paper presented as Poster Presentation at the 2016 SAS Symposium.
として、パワーコンディショナ（PCS）に搭載するリア ルタイムホットスポット検出システムを提案し、その有 効性を示した。1 ところで、平成 29 年に改正 FIT 法の施 行に伴って、システムの設置後にも定期的なメンテナン スが義務化されるため、既設のシステムに対しても、ホ ットスポット検出システムが要求されてきている。そこ で、本論文では既設のシステムに対応した Plug-in 型（後

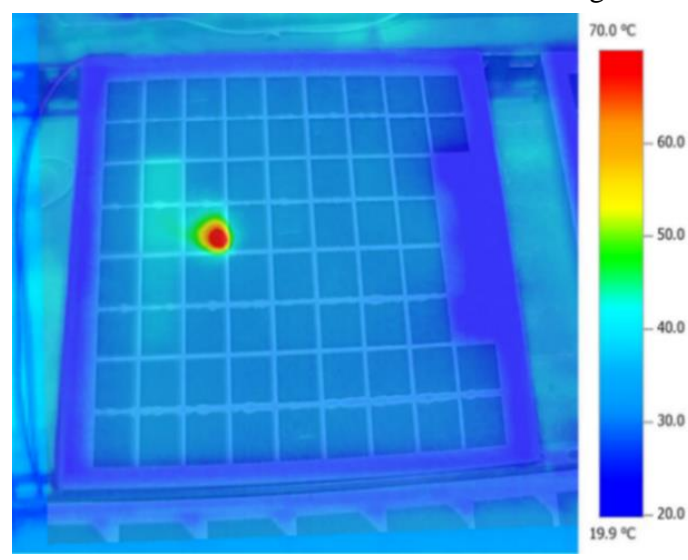

Fig.1. Example of Hot-Spot module. 
付け型）のリアルタイムホットスポット検出システムを 新しく提案し、その有効性を検討した。

\section{PRINCIPLES OF PROPOSED SYSTEM}

\section{II -A. Hot-Spot detection method}

表 1 に今回実験対象とした単結晶太陽電池モジュール の規格を示す。この規格は、基準状態 : モジュール温度 $25^{\circ} \mathrm{C} 、 \mathrm{AM} 1.5$ 、放射照度 $1 \mathrm{~kW} / \mathrm{m}^{2}$ での值である。

Table 1. PV module specifications.

\begin{tabular}{cc}
\hline Articles & Output values \\
\hline Maximum power & $50[\mathrm{~W}]$ \\
Maximum operation current & $3.05[\mathrm{~A}]$ \\
Maximum operation voltage & $16.4[\mathrm{~V}]$ \\
Short circuit current & $3.35[\mathrm{~A}]$ \\
Open ciruit valtage & $20.5[\mathrm{~V}]$ \\
\hline
\end{tabular}

図 2 にモジュールの内部配線図を示す。本モジュール は、2つのセル群（クラスタ）で構成され、それぞれバ イパスダイオードが並列に接続されている。

Cluster A

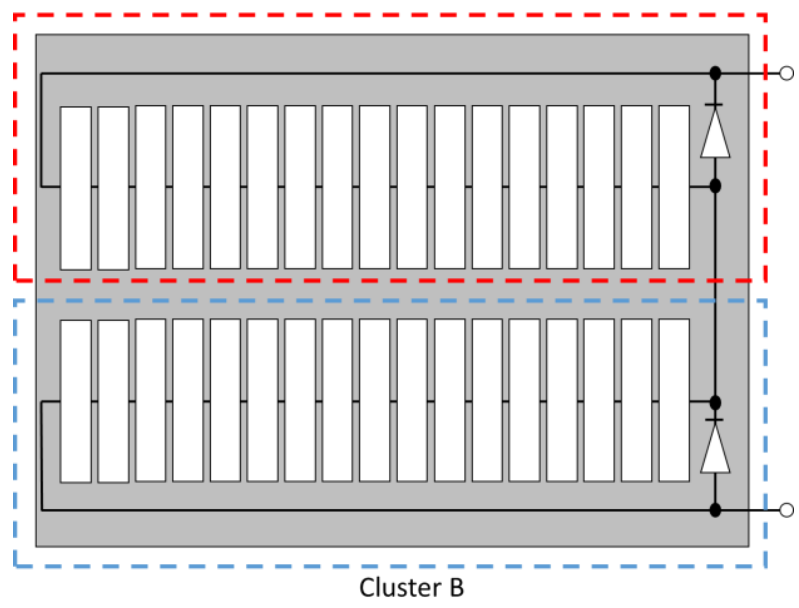

Fig.2. Internal wiring diagram.

本論文では、正常なセルに影を付加した場合を正常モ ジュール、ホットスポットセルに影を付加した場合をホ ットスポットモジュールと呼ぶこととする。正常モジュ 一ルとホットスポットモジュールの電気的特性を調ベ るために、正常なセルまたはホットスポットセルに対し て様々な影を付加し、I-V 特性の測定を行った。図 3 に 影の付加パターンを示す。今回、同図に示す 5 パターン の影（影なし、小影、大影、一枚のセルに影、二枚のセ
ルに影）を付加した。
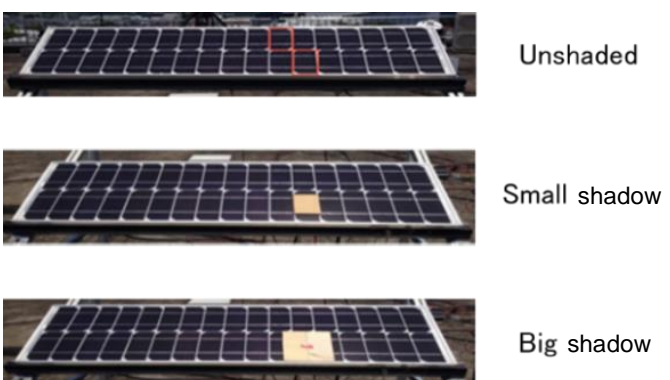

Big shadow

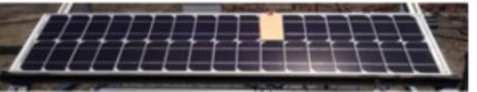

1 cell shaded

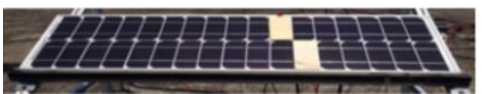

2 cells shaded

Fig.3. Pattern of shading.

図 4 に正常モジュールの I-V 特性、図 5 にホットスポ ットモジュールの I-V 特性を示す。両図から、10 [V]〜 $15[\mathrm{~V}]$ において、正常なセルに影が生じた場合は電流の 変化がほとんどないが、ホットスポットセルに影が生じ た場合は電流は電圧に対して負の傾きを持つことが確 認できる。これは、ホットスポットセルに影が生じると、 そのセルは抵抗で等価されるためである。

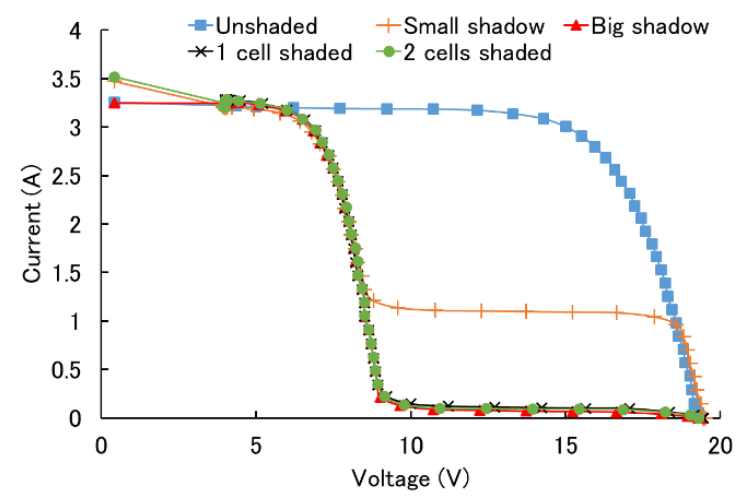

Fig.4. I-V characteristics of normal module.

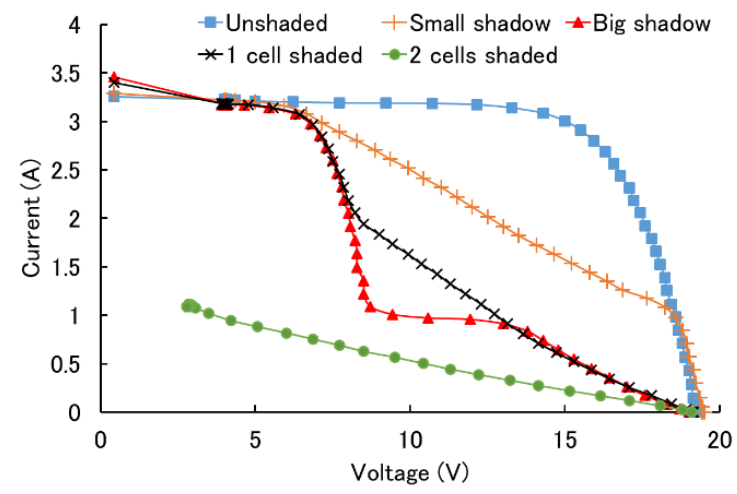

Fig.5. I-V characteristics of Hot-Spot module. 
$\mathrm{V}_{1}=10[\mathrm{~V}]$ 時の電流值 $\mathrm{I}_{1}$ と $\mathrm{V}_{2}=15[\mathrm{~V}]$ 時の電流值 $\mathrm{I}_{2}$ の 差を短絡電流值 $\mathrm{I}_{0}$ で除した值を（1）式のように電流変 化率として定義する。

$$
\text { 電流変化率 }=\left(\mathrm{I}_{1}-\mathrm{I}_{2}\right) / \mathrm{I}_{0} \text {. }
$$

図 4、図 5 の I-V 特性における電流変化率を表 2 に示 す。同表より、影が生じた場合の電流変化率は、正常モ ジュールでは 0.1 より小さく、ホットスポットモジュー ルでは 0.1 以上である。このことから、電流変化率を算 出することで正常モジュールとホットスポットモジュ ールを判別できると考えられる。

本システムでは、“スキャン法”によって定期的に太 陽電池電流をゼロから短絡電流まで変化させて I-V（電 流-電圧）特性を測定する。2この I-V 特性の測定を利用 し、電流変化率を算出することでホットスポットの検出 を行う。

Table 2. Current change rate.

\begin{tabular}{ccc} 
State of shadow & Normal module & Hot-Spot module \\
\hline Unshaded & 0.06 & 0.06 \\
Small shadow & 0.03 & 0.3 \\
Big shadow & 0.02 & 0.13 \\
1 cell shaded & 0.01 & 0.31 \\
2 cells shaded & 0.02 & 0.25 \\
\hline
\end{tabular}

\section{II -B. Proposed Plug-in Hot-Spot detection system}

図6に今回提案する Plug-in ホットスポット検出システ ムの構成を示す。本システムは、昇降圧型 DC-DC コン バータで構成されている。

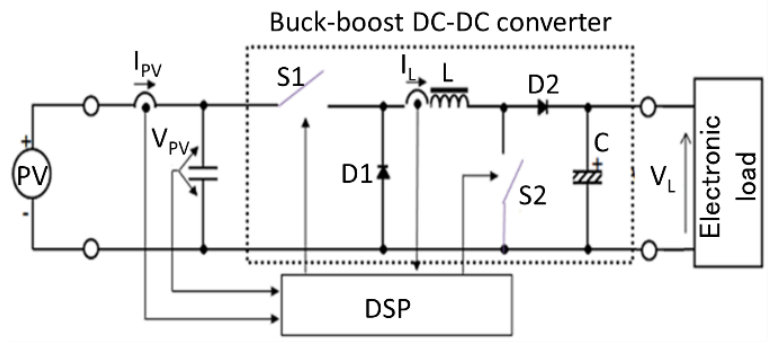

Fig.6. Plug-in Hot-Spot detection system.

本システムは筆者らが先に開発した太陽電池動作点 補正法である “PV ピークブリッジ法”を搭載している。 図 7 に“PV ピークブリッジ法”の動作概念図を示す。 同図に示す P-V (電力-電圧) 特性の実線は、モジュール
に部分影が発生した場合の特性である。従来の PCS に搭 載されている MPPT 制御（Maximum Power Point Tracking） である山登り法では、同図に示すように複数の電力ピー ク点 $\left(\mathrm{P}_{1} 、 \mathrm{P}_{2}\right)$ ができると、低電力のピーク $\left(\mathrm{P}_{2}\right)$ で動 作してしまう場合がある。そこで、“PV ピークブリッジ 法”によって同図に示す破線の電力を仮想的に出力する ことにより、PCS の山登り法でモジュールに影が発生し た場合でも最大電力 $\left(\mathrm{P}_{1}\right)$ を取得することができる。 $\mathrm{PV}$ ピークブリッジ動作は、“スキャン法”の I-V 特性の測定 によって複数の電力ピーク点を検出することで行われ る。

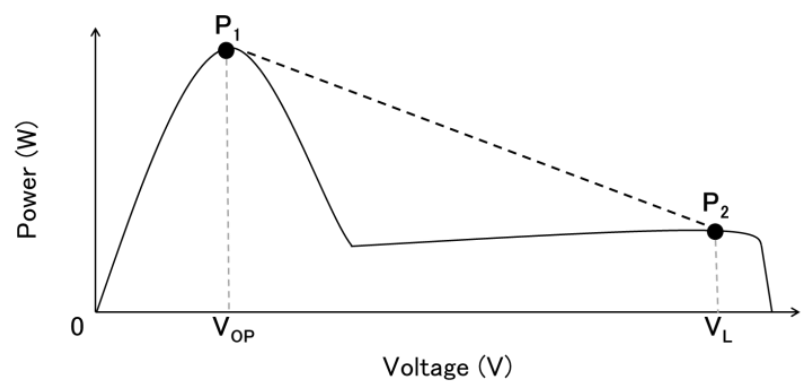

Fig.7. Conceptual diagram of PV peak bridge method.

図 8 に本システムの動作フローチャートを示す。本方 式では、通常待機状態であり、一定のスキャン周期 Ts になると $\mathrm{I}-\mathrm{V}$ 特性の測定を行う。その後、電流変化率の 算出と、動作電圧 $V_{L}$ と最大電力点電圧 $V_{O P}$ の比較が行 われる。電流変化率が 0.1 以上ならシステムから $5[\mathrm{~V}]$ が出力され（ホットスポットフラグ ON）、0.1 未満なら システムの出力はゼロになる（ホットスポットフラグ $\mathrm{OFF})$ 。また、 $\mathrm{V}_{\mathrm{L}}$ と $\mathrm{V}_{\mathrm{OP}}$ が一致するまで $\mathrm{PV}$ ピークブリッ ジによる仮想電力が出力される。

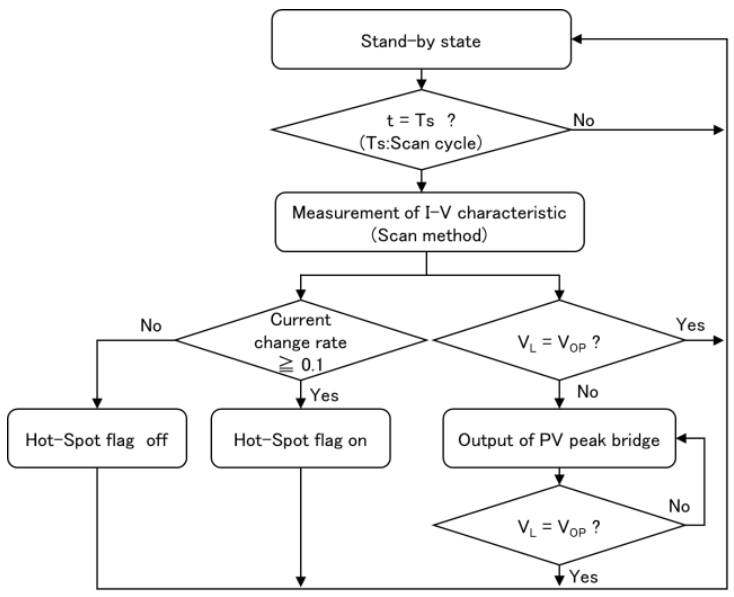

Fig.8. Flow chart of this system. 


\section{EXPERIMENTAL RESULTS}

図 9 に実験を行ったシステムの構成を示す。太陽電池 モジュールの出力が Plug-in ホットスポット検出システ ムに送られ、PV ピークブリッジ動作と電流変化率の算 出が行われる。従来のシステムにおける PCS は、電子負 荷装置に山登り法をプログラミングして用いることで 模擬している。今回の実験では、PV ピークブリッジ動 作と電流変化率の算出を 10 秒毎に行う。電流変化率が 0.1 以上となった場合、ホットスポットが発生している と判定し、本システムが 5 [V] を出力する。そのシステ ムからの出力をオシロスコープで監視し、リアルタイム でのホットスポット検出を行うシステム構成となって いる。

今回の実験は、表 1 に示すモジュールを 1 枚使用して 行った。実験時の日射強度は 800～900［W/m²]である。 また、図 6 に示す Plug-in ホットスポット検出システムの パラメータは、 $\mathrm{L}=7.5[\mathrm{mH}] 、 \mathrm{C}=560[\mu \mathrm{F}]$ 、スイッチ ング周波数 $\mathrm{fc}=20[\mathrm{kHz}]$ である。

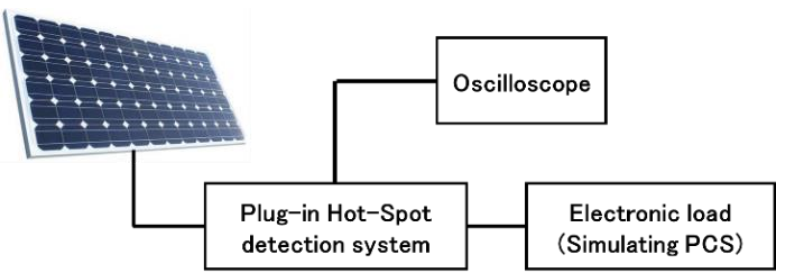

Fig.9. Experimental structure of system.

図 10 に正常モジュールでの実施結果を示す。3 秒時点 で正常なセルに影を付加したところ、太陽電池出力が低 下した。10 秒時点でホットスポット検出が行われたが、 正常モジュールのためホットスポットフラグは OFF で ある。また、PV ピークブリッジ動作によって太陽電池 出力が最大電力へと誘導されて徐々に回復している。34 秒時点で影を取り除くと、太陽電池出力が徐々に回復し

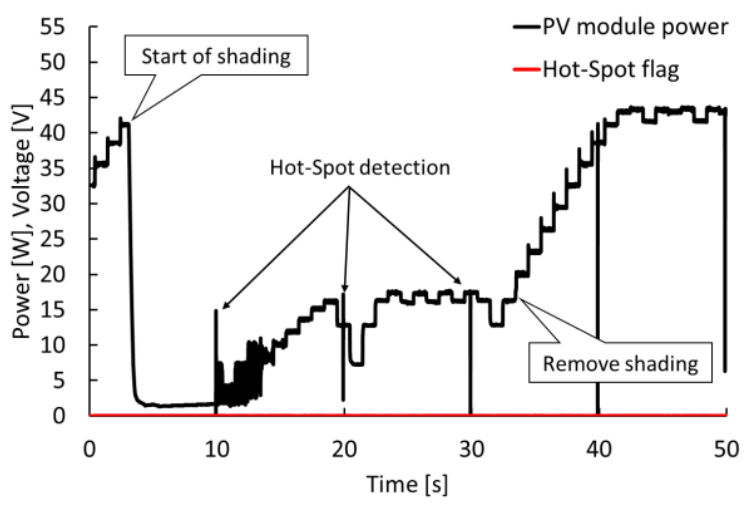

Fig.10. Experimental results of normal module.
た。

図 11 にホットスポットモジュールでの実施結果を示 す。3 秒時点でホットスポットセルに影を付加したとこ ろ、太陽電池出力が低下した。10 秒時点で PV ピークブ リッジ動作によって太陽電池出力が回復し、ホットスポ ットを検出したことでホットスポットフラグが ONにな った。29秒時点で影を取り除くと、太陽電池出力が回復 した。その後、30 秒時点でスキャン動作が行われたこと でホットスポットフラグが OFF になった。

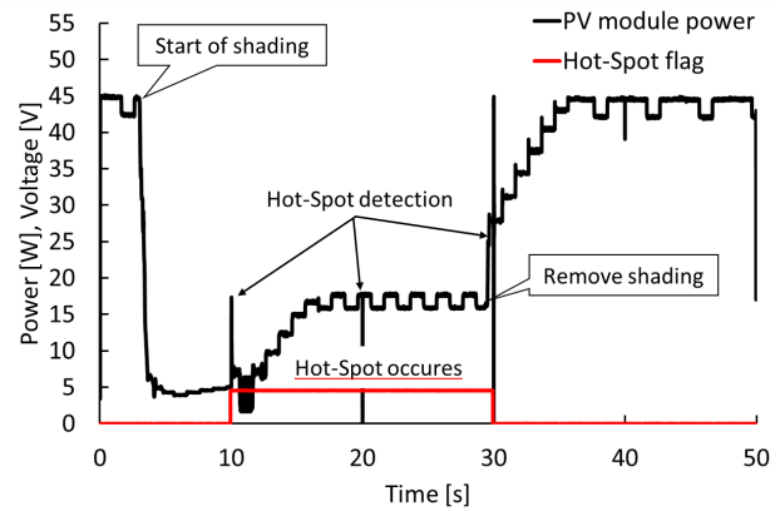

Fig.11. Experimental results of Hot-Spot module.

\section{CONCLUSION}

今回、PV ピークブリッジ法を用いた Plug-in 型のリア ルタイムホットスポット検出システムの有効性を検討 した。実施結果より、本システムによって正常モジュー ルとホットスポットモジュールを判別することができ た。また、モジュールに影が生じた場合でも“PV ピー クブリッジ法”によって太陽電池出力が回復し、本シス テムの有効性が示された。

今後は、複数枚のモジュールを直列に接続したストリ ング構成でのホットスポット検出システムについて検 討を行っていく予定である。

\section{REFERENCES}

${ }^{1}$ B. Hossam and K. Itako, Journal of Advanced Science, Vol. 27, pp. 7-10 (2015).

${ }^{2}$ K. Itako, Y. Togashi, R. Zama and Y. Matsuura, Proceedings of Renewable Energy, 2014 (CD-ROM).

${ }^{3}$ K. Itako, B. Hossam, T. Kudoh, and Q. Huang, Proceedings of in Industrial Electronics Society, IECON, 2015-41st Annual Conference of the IEEE, pp. 1032-1036. 